\title{
THE NEED FOR CO-ORDINATED RESEARCH
}

\section{J. C. BEENHAKKER B.Sc. (Physiotherapy) (Witwatersrand) D.P.E. (Witwatersrand)*}

Research in all fields of physiotherapy, which is long overdue, can only result in improved patient care. We must be sure that our treatment programmes do have the effects that we are hoping to achieve, which will only occur when these effects are investigated and the results of the findings analysed.

Too long have modalities been used 'because they work'! If we do not know why they work, how can we be sure that something else will not be more successful? I often have the feeling that our patients improve in spite of physiotherapy!

Evaluation of the delivery of health services to the batient as well as the community is required. Are we making the best use of available resources? We need to investigate the effects of our various modalities on normal tissue and endeavour to determine whether these effects are altered by injury or disease. We will have to design and construct measuring devices which will give an objective method of assessing a patient's response to treatment, and research into the most effective and reliable tool is required.

Research is the natural result of attempting to find answers to questions. Every physiotherapist must have come up against some problem in her work, yet very few have set out to solve this on a scientific basis. Each one of us is in a position to test a theory, whether this is in the clinical field or of a more academic nature, yet how often is this done?

If research is being done, why do not more physiotherapists know about it? It would seem that there is a pressing need for co-ordination of research projects both at an undergraduate and a postgraduate level.

* Acting Head, Department of Physiotherapy, University of Witwatersrand.
Physiotherapists who are involved in research projects or clinical trials, or those who would like to become involved, have very little idea of what is being done in South Africa. Even the worthwhile trials and surveys which have been written up, often lie forgotten in cupboards or on library shelves.

In order, therefore, to promote interest in research, a group was formed by the Physiotherapy Department at the University of the Witwatersrand. The aims of this group are to discuss problems in, and methods of research, to co-ordinate research efforts, to provide a platform to disseminate knowledge and provide a stimulus for further research.

This group of academic staff and practising clinicians meets every two months. Topics discussed have covered a wide field, including problems encountered by various workers and how these were resolved, the availability of research facilities, organisation of material and the method of writing up a dissertation. A tape on "Research in Spinal Therapy" stressed the importance of the involvement of the clinician in the design of the experiment and the study of its clinical effectiveness.

Workshops are planned for 1979 and speakers will be invited to lead discussions in specialised areas. The results of trials and experiments undertaken by undergraduate students will be correlated in order to establish areas for further research.

It is felt that a group, such as this, could offer a co-ordinating service for research. Although the group is confined to the Johannesburg area, its activities could be expanded to a national level, if there was a sufficient need.

If any physiotherapist is interested in joining this group, they should contact the writer at the Physiotherapy Department of the University of the Witwatersrand. 


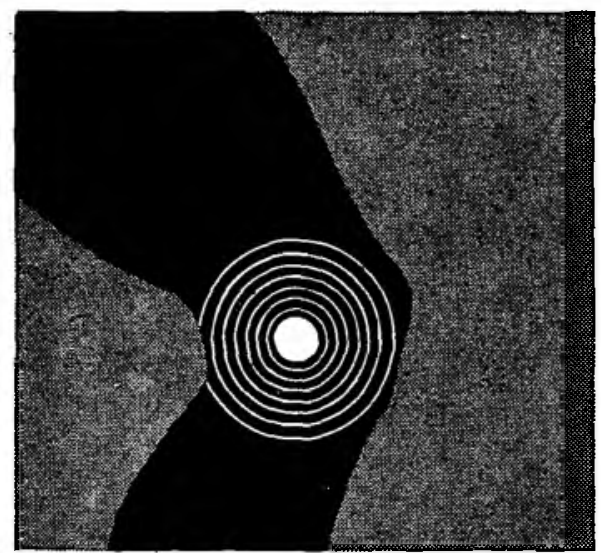

1. Rheumatic pains in joints and muscles

3. Muscle cramps and stiffness

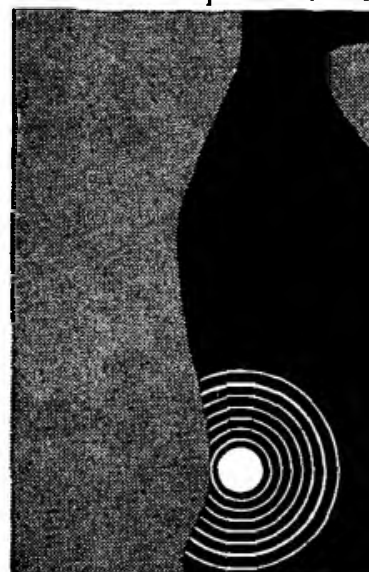

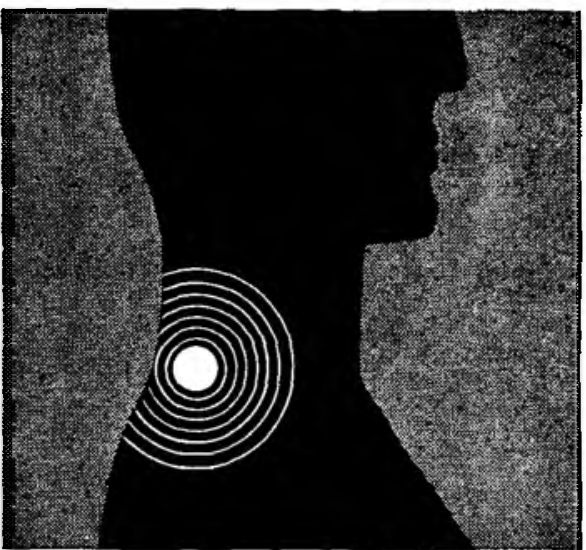

2. Fibrositis

4. Other local pains and aches

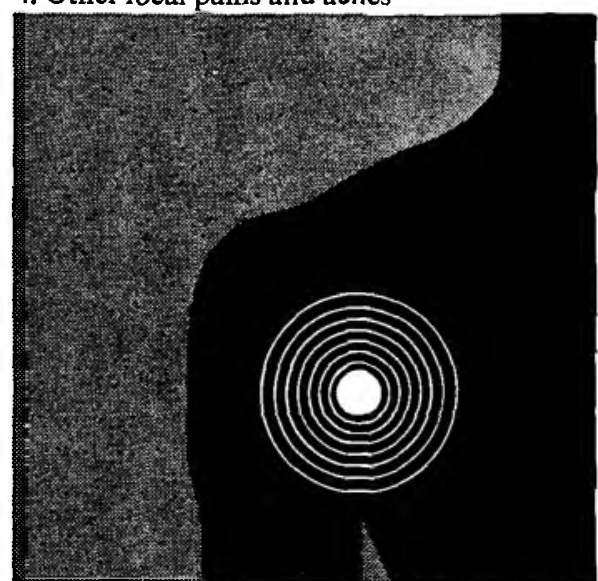

\section{pain is our scene...}

\section{analgen ointment}

Formulation: Two pain-killing ingredients, diethylamine salicylate and nopoxamine, in a special ointment base to speed subcutaneous penetration.

Indications: Rheumatic pains in joints and muscles, low backache, fibrositis, sprains and bruises, muscular cramps and stiffness, neuralgic pains.

Action: Soothing, deep-penetrating, rapid pain relief with local anaesthetic effect.

Application: Massage gently into the skin around the affected area until completely absorbed. Apply as often as required.

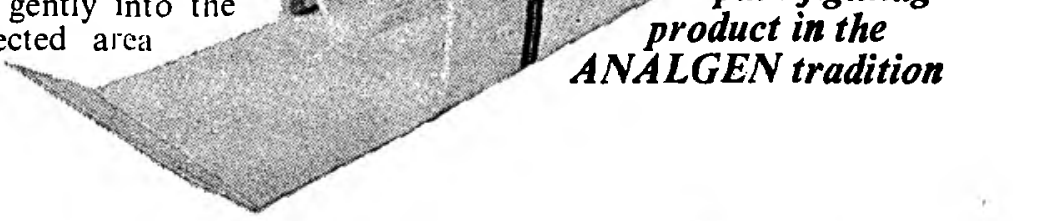




\section{NEWS FROM SPECIAL INTEREST GROUPS}

Lecturers Group of S.A.S.P.:

Secretary: Miss S. Irwin-Carruthers,

Physiotherapy Department,

P.O. Box 63,

Tygerberg,

7505.

Manipulative Therapists Group of S.A.S.P.:

Secretary: Mrs. C. Edwards,

Erin Villa,

5 Lower Trill Road,

Observatory,

7925 .

National Hospital Group of S.A.S.P.:

fecretary: Miss P. Bowerbank,

605 Tivoli Flats,

9 th Avenue,

Wonderboom South,

Pretoria.

0084 .

Obstetric Association of S.A.S.P.:

Secretary: Mrs. H. B. Kastell,

26 Desborough Ave.,

Winston Ridge,

Johannesburg,

2196.

Tel.: 40-4557.

Private Practitioners' Association of S.A.S.P.:

Secretary: Miss B. Winter,

936 Libertas Medical Centre,

Goodwood,

7460 .

\section{S.A. Neurodevelopmental Therapy Association:}

Secretary: Mrs. M. van der Spuy,

c/o Vista Nova School for Cerebral Palsied Children,

Milner Road,

7700 Rondebosch.

\section{NATIONAL HOSPITAL GROUP}

\section{Dear Colleagues}

During the middle of last year we circulated to all of you who are attached or interested in hospital work a letter of introduction to our group.

Although we were not impressed by the quantity of the replies, the quality of the replies we received reflected that those of you who did take time to reply showed a sincere interest in improving the standard of physiotherapy as well as updating their own knowledge and skills. Others showed a deep concern over the present state of conditions of service. We are hopeful that there will be an improvement in the salary scale during this year.

The Transvaal branch has at present over sixty members and is extremely active. Meetings are held every two months in different physiotherapy depart- ments. Two very successful day workshops were run last year on the treatment of hemiplegia and the treatment of the knee.

How about the other larger centres?

All of you who were excited about our proposed subject for a symposium on job satisfaction, will be pleased to hear that Dr. Sandra van der Merwe is to conduct such a workshop at the pre-council congress on Monday 23 April in Cape Town. We hope to see as many of you as is possible at this workshop and also extend a warm invitation to a sherry party and annual general meeting on the 24 April.

For those of you who cannot join any of the meetings or functions we have the good news that our first newsletter will be coming out soon.

Thank you for all your interesting replies, we welcome continuing correspondence on any subject related to our group.

Best wishes.

Elsa Smith (Chairman) Pat Bowerbank (Secretary)

\section{THE OBSTETRIC ASSOCIATION}

"Baby Spectacular '78" was arranged by The Leo Club of Highpoint, Johannesburg. To explain who they are, here is the President's message:-

"Leo's is a Project of Lions International. The Lions through their Youth Programme have enabled us at Leo's to promote service activities among the youth of the community which develop the individual qualities of Leadership, Experience and Opportunity.

The object of the Leo Programme is to provide the youth of the world an opportunity for development and contribution individually and collectively as responsible members of the local national and international community.

The motto of the Lions and Leo's Organisation is "We Serve". It is through service, I believe, that will have attained these goals."

Several para-medicals, including the Obstetric Association of the S.A.S.P., concerned with babies and the growing child, were asked to exhibit at the Show held at Milner Park Show Grounds, Johannesburg on Saturday November 25.

Several posters were displayed on ante-natal and post-natal physiotherapy, such as "Backache" "Fitness during pregnancy" and "Getting back to normal". Motherhood booklets and bibs, which were kindly donated by Lederle Laboratories, and pamphlets on "What is Obstetric Physiotherapy?" were distributed.

The response of the public to "Baby Spectacular" was tremendous, particularly in the entries for the baby show competitions where literally thousands of babies flocked!

Mrs. Mathias and Mrs. Goodman were two of the exhausted members of a dedicated team of judges, who attempted to judge the babies on their neurodevelopment as well as their beauty. This project was so successful that the organisers have decided to make it an annual event. 


\section{PRIVATE PRACTITIONERS ASSOCIATION}

W.C.A.

Many private practitioners are dissatisfied with the rule requiring prior permission for treatments in excess of twenty. The problems arise when the medical advisor to the Commissioner disagrees with the patient's doctor whether more treatment is required. The Executive Committee has written to the Medical Association with permission of N.E.C. to try and enlist their help, as the problem affects their patients and their recommendations. Please contact the secretary if you have any problems with this, giving all the details of the case, so that we may substantiate our complaint.

Committee News

The Chairman of the Eastern Province Branch (Port Elizabeth) will be Mrs. L. Erasmus from the 15 th January, 1979. She replaces Mr. E. van Wyk on the Executive Committee. The Committee requires an advertising manager for the directory. Please contact Mrs. Pilkington at (021) 69-5537 if you can help. You need not live in Cape Town. At the time of going to press the A.G.M. will have been held. A report will be submitted for the next issue of the journal.

\section{WANTED}

Machines and equipment for new private practice. Phone Johannesburg 40-4023, mornings only.

\section{FOR SALE}

Well established practice in Johannesburg area for sale. For details write to P.O. Box 78241 Sandton.

\section{SENIOR PHYSIOTHERAPIST}

Day Hospitals Organisation, Karl Bremer. Salary:

The minimum commencing salary is R4 290 plus a pensionable allowance. Provision exists for the recognition of previous experience for salary purposes.

\section{Qualification:}

Qualification in Physiotherapy acceptable to S.A. Medical and Dental Council.

Excellent privileges - Information and application forms (Staff 23) are obtainable from the Medical Superintendent, Day Hospitals Organisation, Private Bag No. 2, P.O. Karl Bremer, 7531.

Application forms should be submitted to the Director of Hospital Services, P.O. Box 2060, Cape Town 8000 to reach him not later than 14 March 1979. THE SOUTH AFRICAN SOCIETY OF
PHYSIOTHERAPY

President

MR. JAMES J. CRAIG

Vice-Presidents

PROFESSOR T. L. SARKIN

PROFESSOR L. SOLOMON

DR. J. A. VAN DER MERWE

PROFESSOR J. A. VAN VUREN

PROFESSOR F. ZIADY

Honorary Life President

PROFESSOR B. BROMILOW-DOWNING

Honorary Life Vice-Presidents

MISS LOIS DYER

MISS JEAN BLAIR

MR. A. ROTHBERG

Chairman

MRS. K. M. LEVY

Immediate Past-Chairman

MISS MARGARET EMSLIE

Vice-Chairmen

MRS. A. MATHIAS

MISS E. M. BOITING

General Secretary: All correspondence to P.O. Box 11151, Johannesburg 2000. Tel. 726-8040.

General Treasurer: MISS N. H. BAINES

Journal Editor: Mrs. J. A. C. GILDER. 8 Clee Road, Observatory, Cape 7925.

Minute Secretary: MRS. J. WELLS.

National Executive Committee: Miss P. Bowerbank, Mrs. F. Glauber, Mrs. N. Lennard, Mrs. A. McFarlane, Miss L. Pretorius, Mrs. S. Keays.

Appointments Information Secretary: Miss Priscilla Blake, South African Society of Physiotherapy, P.O. Box 11151, Johannesburg.

\section{BRANCH SECRETARIES}

Border: Mrs. W. J. Hudson, 15 Lagoon View Drivd Beacon Bay, East London 5241.

Eastern Province: Miss H. Smith, 1404 Oasim North, Havelock Street, Port Elizabeth 6001.

Goldfields: Mrs. M. van den Berg, P.O. Box 296, Welkom 9460.

Natal Coastal: Miss S. H. M. Blackwood, 31 Blue Heights, Westville 3630 .

Natal Midlands: Mrs. A. Londt, 54 Moss Place, Montrose, Pietermaritzburg 3201.

Northern Cape: Mrs. C. K. van Rensburg, P.O. Box 25, Kimberley 8300.

Northern Transvaal: Mrs. D. E. Beukes, P.O. Box 27804, Sunnyside, Pretoria 0132.

S.O.F.S.: Mrs. R. H. van Blerk, 94 Waverly Road, Waverley, Bloemfontein 9301.

Southern Transvaal: Mrs. J. Beenhakker, Sub-Department of Physiotherapy, Medical School, Hospital Street, Johannesburg 2001.

Western Province: Miss M. S. Uys, Department of Physiotherapy, P.O. Box 63, Tygerberg, Cape 7505. 